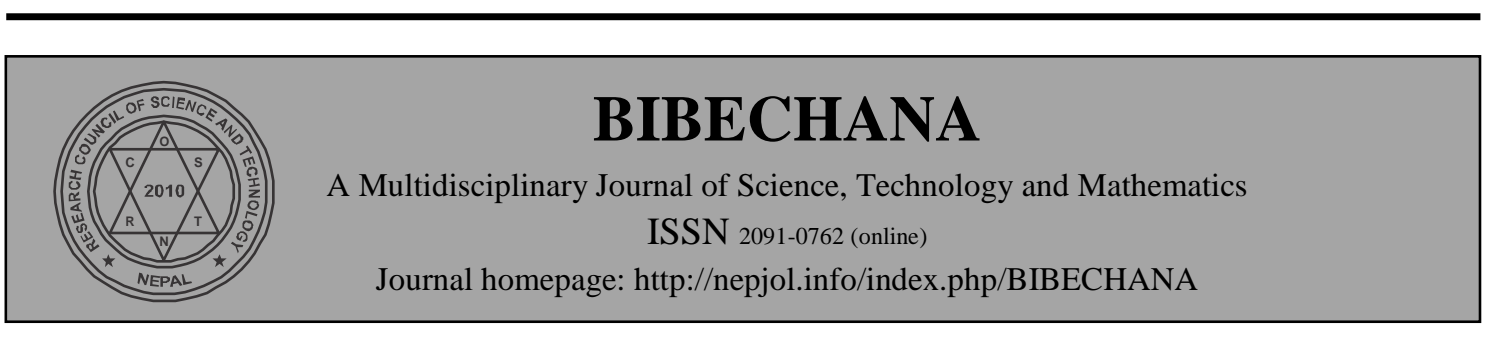

\title{
Chromogenomic changes after the use of methyl parathion on Ocimum Americanum L. in Eastern Zone of Nepal
}

\author{
K.K. Mishra \\ Department of Botany \\ M.M.A.M. Campus, T.U., Biratnagar, Nepal \\ Accepted for publication: February 04, 2014
}

\begin{abstract}
Fungicide like methyl Parathion was able to control the fusarial disease of Ocimum americanum L. but it caused Chromogenomic changes in the first progeny of the host plant. The parental colour was red, which became to green in the ratio 5-95\%. Therefore, the use of the fungicide not only control the disease caused by the Fusarium oxysporum but also affects the genomes responsible for the colour. The investigation was from 1/11/2012 to $02 / 12 / 2013$.
\end{abstract}

(C) 2014 RCOST: All rights reserved.

Keywords: Chromogenomic changes; Methyl parathion; Ocimum americanum L.

\section{Introduction}

The host plant showed the presence of microconidia and megaconidia of F. oxysporum in the twig and leaf of Ocimum americanum L. under the anatomical study along with the following symptoms:

$\begin{array}{cll}\text { PLANTS } & \text { HEIGHT } & \text { BRANCHES } \\ \text { I } & 60 \mathrm{~cm} . & 16 \\ \text { II } & 55 \mathrm{~cm} . & 11 \\ \text { III } & 35.5 \mathrm{~cm} . & 9\end{array}$

\section{CALCULATION OF SPORES:}

SYMPTOMS

Lesser white

White vascular tissue very clear

Least white, terminating

brownish black, presence of air canal.

i.e. breakage of xylem \& phloem.

A) SMALLEST TWIG: epidermal and vascular region.
(i) Micro conidium-
(ii) Mega conidium - 1

ROOT-HAIR:

(i) Mycelium - (+)

(ii) Micro conidium - unicellular, No -2

(iii) Mega conidium - only one.

B) INTER MEDIATE TWIG:
(i) Mycelium - ( \pm
(II) Xylem lumen - Mycelium, Megacondidium - 1, 5- septate condition. 
C) LARGEST TWIG:

(I) Mycelium - ( \pm )

(II) Microconidium - $( \pm)$

(III) Mega Conidium $-( \pm)$ in the cortical region of stem.

The identification was followed as described by Wollenweber and Reinking [1-3], and Synder [4].

The pathogens of Fusarium oxysporum during its different stages of growth - i.e. mycelia, mat of mycelia, microconidia and megaconidia librates several toxic substances to lnactive the cell, tissues or lysis of different parts particulary xylem and pholoem of the host Ocimum americanum L [5]. Here, Fusaric acid is the most important and viable toxin, secreted by F. oxysporum. It caused vein clearing, epinasty, reduction in respiration and growth. Necrosis of cortical tissues overlying the vascular bundles, Furrowing of stem, deposition of salts on stem and sometimes bending of stem. Kalyansundram \& Venkatraman [6,7] have shown that a concentration of $10^{-4} \mathrm{M}$ of fusaric acid is reached in the infected plants. This condition is lethal to host tissues [8] described phytotoxins produced by fusaria [9].

The fungicide methyl parathion was used through spraying on the plant, soil and surrounding. It resulted to control the disease fusarial wilt' on the host plants of Ocimum americanum L. The theme or vision 2030 of Indian phytopathological society, New Delhi, India. Methyl parathion parathion is the chemical control of the pathogen and known as methyl parathion 2\% D.P.

The first progeny obtained by the seeds of treated host plants of Ocimum americanum L. were free from the fusarial disease but the colour of the leaves of the plant was mixed condition of red and green, though the parental leaves were red. The different ration of the red and green leaves is given in the following tables.

\section{PLANT RED LEAVES GREENLEAVES} OCIMUM AMERICANUM 1.

(i)
$5 \%$

$11 \%$

$20 \%$

$30 \%$

$35 \%$

$40 \%$

$50 \%$

$55 \%$

$70 \%$

$95 \%$
$95 \%$

$89 \%$

$80 \%$

$70 \%$

$65 \%$

$60 \%$

$50 \%$

$45 \%$

$30 \%$

$5 \%$

The calculation of green leaves and red leaves was done, counting the number of leaves on each branch of the plants. 


\section{Conclusion}

The use of fungicide is essential to control the fungal diseases but it has some side effects also as chromogenomic changes in the first progeny of the treated host plants of Ocimum americanum L. by the fungicide methyl parathion.

\section{References}

[1] W.C. Synder, H.N. Hansen, Amer. J. Bot., 27 (1940) 64.

[2] W.C. Synder, H.N. Hansen, Amer, J. Bot., 28 (1941) 738.

[3] W.C. Synder, H.N. Hansen, Amer, J. Bot., 32 (1945) 657.

[4] W.C. Synder, Current status of Taxonomy in Fusarium sp. And their perfect stages phytopathology, 55 (1965) 833.

[5] K.K. Mishra, Date palm without date due to Fusarium Oxysporum var. Toddy in Eastern zone of Nepal. 95 ${ }^{\text {th }}$ Indian Science Congress, Jan 3-7, 2008, Vishakhapatnum, 87.

[6] R. Kalyansundram, Proc. First Int. Symp. Pl. pathology, IARI, New Delhi, (1970) 135.

[7] R. Kalyansundaran, Some concept of toxin in the plant disease physiology of host pathogen interaction (A. Mahadevan ed.) Today \& Tomorrow's Printers \& Publishers, New Delhi, 1977.

[8] H. Kern, "Phytotoxins produced by Fusaria" in phytotoxins in plant diseases, 1972.

[9] K.K. Mishra, The fungicide around the fusarial conidia of Ocimum americanum L. at Biratnagar Nepal, 100 ${ }^{\text {th }}$ Indian Science Congress, 3-7 Jan. 2013, Kolkata, 98. 